Objavljeno naučno izlaganje na konferenciji

UDK: 365-053.9(497.11)

728.1-053.9(497.11)

ID: 212277772

\author{
Ljubica Milosavljević \\ Naučni saradnik, Institut za etnologiju i antropologiju \\ pri Odeljenju za etnologiju i antropologiju \\ Filozofski fakultet, Univerzitet u Beogradu \\ Čika Ljubina 18-20, 11000 Beograd, Srbija \\ ljmilosa@f.bg.ac.rs
}

\title{
DOMOVI ZA STARE I OSTALE „DRUGE”*
}

\begin{abstract}
Apstrakt: Rad ima zadatak da, kroz upotrebu antropološke perspektive, ukaže na neke od načina na koje se prožimaju socio-kulturni i zdravstveno-biološki aspekti vezani za starost. Primeri na kojima će to biti moguće pokazati jesu domovi za stara lica koji su u novijoj istoriji, između ostalog, preuzeli ulogu pružanja zdravstvenih usluga svojim korisnicima. Ono na čemu će rad posebno insistirati jeste proučavanje kategorizacije domskog smeštaja koja ukazuje na ujedinjavanje u problemu (i smeštaju) različitih ugroženih kategorija društva, bilo da se radi o starima bez imovine i primanja ili mlađih pripadnika društva koji usled siromaštva i/ili bolesti (najčešće mentalnih) utočište nalaze, upravo, u domovima za stara lica. Višeslojnoj ulozi ovih ustanova valja pridodati i osnovnu namenu koja se sastoji u pokušaju pružanja što optimalnijih uslova života penzionisanim građanima, kojima su domski kapaciteti u najvećoj meri okrenuti. Ovaj rad je, na izvestan način, i prikaz razvojnog puta brige o starima (i ne samo o njima) u okvirima domskog zbrinjavanja - od uboških domova do savremenih gerontoloških centara. Kako je prvobitni vid organizovnog rešavanja problema vezanih za siromaštvo, nemoć i/ili starost pripadao gradskim sredinama, tako je i mreža domova za stara lica, čijoj se izgradnji pristupilo nakon Drugog svetskog rata, pripala sferi urbanog. Bliži uvid u prostorna, ali i teritorijalna rešenja u građenju ove mreže pomoći će u osvetljavanju položaja ostarelog čoveka u društvu, u kojem je osnovna karakteristika konkretnih domskih kapaciteta njihova nedovoljnost.
\end{abstract}

\footnotetext{
* Rad je prezentovan na Međunarodnoj naučnoj konferenciji „Urbani gradski prostor i zdravstvena kultura u Beogradu" održanoj 19. i 20. novembra 2012. godine na Filozofskom fakultetu Univerziteta u Beogradu i predstavlja rezultat istraživanja na projektu „Antropološko proučavanje Srbije - od kulturnog nasleđa do modernog društva" (ev. br. 177035) Ministarstva prosvete, nauke i tehnološkog razvoja Republike Srbije.
} 
Ključne reči: dom za stara lica, siromaštvo

$\mathrm{Ne} \mathrm{MeSH}$ : starost, „drugi”

Key words: old age homes, poverty

Non MeSH: old age, „others”

\section{Uvod}

Pokušaju analize uslova institucionalnog zbrinjavanja u starosti danas, koji podrazumeva pružanje usluge stanovanja, ali i medicinske nege - izrazito važne kada je reč o starijoj populaciji - biće pristupljeno, najpre, kroz osvetljavanje najranijih faza $\mathrm{u}$ procesu konstruisanja starosti kao društvenog problema i to onog njegovog dela ${ }^{1}$ koji se odnosi na organizovano stanovanje tj. na formiranje prvih prihvatilišta za stare. Istorijska dubina za kojom se poseže ima za cilj da uputi u izvesnu sličnost između nekadašnjih društvenih i državnih strategija za rešavanje problema najstarijih i aktuelnog stanja u konkretnoj oblasti. Kao jednu od ujedinjavajućih karakteristika, svakako ne i jedinu, valjalo bi apostrofirati „drugost”, konstruisanu uključivanjem svakovrsne nemoći skopčane najčešće sa siromaštvom, u okviru koje starost biva prepoznata kao društveni problem, a koji se, delom, rešava u okviru ustanova čijoj analizi je posvećen ovaj rad. Starost će, dakle, u ovom prilogu biti analizirana, prevashodno, kao socio-kulturni fenomen zaviseći od ukupnih procesa u društvu koji čine da neke karakteristike rešavanja problema vezanih za poslednju etapu života uporno ostaju u okvirima rešavanja širih društvenih problema i/ili pripadaju margini.

Sagledavanje starih lica u korpusu nemoćnih i marginalizovanih upravo na primeru domske prakse ima za cilj da ukaže na dugotrajno ujedinjavanje u problemu različitih kategorija nevoljnika koji bivaju smešteni u označene ustanove prema kriterijumu socijalne potrebe tj. ugroženosti različitog tipa. Usled označenog izjednačavanja životni prostor danas, kao i nekada, često dele stara lica, psihički izmenjene osobe, psihijatrijski bolesnici, lica sa invaliditetom, izbegla lica, nedovoljno intelektualno i emotivno razvijene osobe, beskućnici, alkoholičari i svi oni za koje društvo i nadležne institucije nisu pronašli bolje rešenje. Ovo dirigovano ujedinjavanje po kriterijumu nemoći, stoga, obavezuje na osvetljavanje početaka označenog potprocesa ukupnog procesa konstruisanja starosti kao društvenog problema „koje postaje moguće tek usled profilisanja/konstruisanja različitih društvenih problema, a koji su prvobitno zajedno tvorili problem nemoćnih i/ili siromašnih". [3] Ovaj proces pratila je i profesionalizacija zasnivanjem pojedinih praksi i naučnih gledišta koji su, između ostalog, omogućili da starost postane samostalni (mada ne u potpunosti) društveni problem. Označenom postupnošću bilo je moguće postepeno smenjivanje mera za

1 Drugi, u velikoj meri, preklapajući potproces ukupnog procesa konstruisanja starosti kao društvenog problema podrazumeva dekonstruisanje uslova koji su vodili uvođenju penzija, formiranju penzionih fondova i sazdavanje penzionisanog dela društva u punom obimu [1]; pri čemu se konstruisani društveni problem shvata na način na koji to čine Spektor i Kicus. [2] 
saniranje šireg društvenog problema siromaštva usmerenijim i, najzad, specijalizovanim merama i akcijama koje su omogućile da se pređe put od zbrinjavanja starih $u$ uboškim domovima i ispovednim bolnicama do osnivanja savremenih gerontoloških centara. Razlike su izrazite i jasno omeđujuće. Ipak, ovaj rad neće insistirati na njima već na prepoznavanju izvesnih sličnosti u istorijskom sledu koje jasno izdvajaju stare i ostale „druge” u gradskoj sredini u kojoj starost kao društveni problem biva konstruisan. [4]

\section{Domovi za gradsku sirotinju kao domovi za stare - model za ugledanje}

Pojavu prvih organizovanih akcija za zbrinjavanje ubogih (koji u literaturi najčešće objedinjavaju: siromašne, nezaposlene, nemoćne, bolesne, beskućnike... ali i stare) moguće je registrovati na teritoriji vojvođanskih gradova u periodu Austrougarske monarhije, koja će zadugo biti prvi model za ugledanje prenet u okvire samostalne srpske države u XIX veku. Konkretni model podrazumevao je specifičan vid brige o ugroženima i moguće ga je prepoznati u brizi koje su pružale nekadašnje bolnice ${ }^{2}$ pod nazivom špitalj. Prema zaključcima domaće gerontološke literature, srednjevekovne bolnice, koje će uticati na novovekovne prakse, imale su pretežno socijalni karakter, dok će do prevage medicinskog doći znatno kasnije. Zaključci do kojih se došlo u okviru socijalnog rada nešto su drugačiji i apostrofiraju da je osnovni sadržaj rada bolnica bio lečenje obolelih, pa tek onda smeštaj i zbrinjavanje ostarelih i iznemoglih. [5 p 26] Ono što je, svakako, neupitno jeste to da je u ovim bolnicama moguće prepoznati prve postupke zbrinjavanja starih, bez obzira na to da li se radi o primarnoj funkciji ili ne.

Veroispovedne bolnice, otvarane na teritoriji bogatih vojvođanskih gradova $\mathrm{u}$ XVIII veku, naime, nastavljaju staru praksu manastirskih i kasnije gradskih sredina. Imale su zadatak, da, između ostalog, leče siromašne i beskućnike, među njima i stare. Za ovaj period karakteristična je transformacija bolesti u medicinski fenomen koja time biva shvaćena kao ona koja se može i mora lečiti, [6 pp 239 - 263] što dalje vodi sazdavanju preduslova za odvajanje zdravstvene sfere kao samostalne. Ipak, razgraničenje između ustanova zdravstvenog tipa i onih koje su imale karakter svratišta i uboškog doma neće biti odmah u potpunosti moguće, iako su onovremene monarhističke reforme vodile u tom pravcu. Zbog toga je uboge, uboške ili sirotinjske domove moguće razumeti kao „prve” bolnice koje su pružale pomoć onima kojima je bila potrebna, ali i kao „prve” domove u kojima su stari nalazili utočište. Primer takve bolnice, nazvane „srpski hospitel” postojao je u Novom Sadu u prvoj polovini XVIII veka. [7 pp 11-21]

$\mathrm{Na}$ organizovanu brigu o siromašnima, time i starima koji su bili siromašni, najviše je uticaja imalo donošenje Centralnog zakona Habsburške monarhije 1745. godine, koji je nalagao osnivanje „utočišta za sirotinju” u kojem je bila smeštena „sva sirotinja bez obzira na uzrast, pol i zdravstveno stanje”. [8 p 15] Primer ovakvog

\footnotetext{
2 Kasnija upotreba termina špitalj podrazumevaće savremeniji vid bolnice.
} 
organizovanja moguće je naći u studiji Prosjaci u Subotici Gašpara Ulmera. [9] Prve akcije za uspostavljanje institucije zbrinjavanja siromašnih i nemoćnih u ovom gradu zabeležene su 1787. godine.

Osnivanje ovog tipa ustanova, opšte uzev, bilo je vezano za gradske sredine koje su primale veliki broj pridošlica u potrazi za poslom i životnim boljitkom. Međutim, „onih koji nisu mogli da se uklope u postavljene norme nije bilo malo. Bili su to ljudi bez kuće i imanja, sirotinja, bećari, skitnice, probisveti i razbojnici". [6 p 170] Porastom broja žitelja gradova, uvećavao se i broj gradske sirotinje, ali ono što za ovaj prilog ostaje najvažnije jeste da je „kroz njeno zbrinjavanje pronađena $\mathrm{i}$ "pukotina” u kojoj su mesto našli i ondašnji gradski ugroženi starci i starice”, [3] što se može pokazati na više primera. Prvi od njih ukazuje na to da su se najsiromašniji bavili prosjačenjem a da su vlasti, sa druge strane, nastojale da kontrolišu broj prosjaka redovnim popisima i insistiranjem na otvaranju prihvatnih ustanova. Primanje u ove ustanove pratio je razrađeni sistem pravila tako da su u „bednu kuću” u Subotici bili primani „samo oni starci i siromašni bolesnici koji više nisu mogli prositi i koji su bili napušteni tj. nisu imali nikoga bližnjeg koji bi se mogao brinuti o njima”. [9 p 61]

U slučaju Novog Sada u kojem je, kako je rečeno, u XVIII veku postojala bolnica tj. ubožnica važno je istaknuti da su postojali državni pritisci da se osnuje i „državni ubogi dom”. Međutim, u izvorima se sirotinjska kuća u Futogu pominje tek od kraja XVIII veka, kada Magistrat nalaže popisivanje prosjaka pravoslavnim i katoličkim sveštenicima: „kako bi ih, ukoliko pristanu, smestili u sirotinjske, odnosno uboge domove". [7 p12]

Bilo je i primera da su lokalni moćnici podizali utočišta, poput veleposednika Antuna Fernbaha koji je 1888. godine, pod okriljem katoličke crkve, osnovao uboški dom u Apatinu. Jedan od najstarijih domova podignut je 1831. godine u Staroj Moravici; 1896. godine u Molu; [19] dom u Bečeju podigli su supružnici Jožef Frajn i Irena Bem 1905. godine kao: „znak ljubavi prema stanovnicima ovoga grada svakoga reda, vere i jezika u kome će siromašni, ubogi i od sudbine prognani svoj odmor naći i za čijim će se stolom hraniti”. [8 p16] Monografija Gerontološki centar Zrenjanin vek organizovane društvene brige o ostarelim licima [10] otkriva da briga o starima u Zrenjaninu traje od druge polovine XIX veka, a da su njeni kriterijumi bili definisani u poslednje dve decenije pretprošlog veka - „tražen je, naime, način da se reši najveći problem organizovane zaštite starih lica, a to je, stalni kolektivni smeštaj”. [10] Uslovi smeštaja siromašnih ljudi u Dom ubogih bili su strogo regulisani. Zabranjivani su: svađa, održavanje polnih odnosa, psovanje, zaduživanje, pijančenje i vršenje protivprirodnog bluda. [10 pp 7-9] Podaci o datumu prijema u Dom i iz Matične knjige umrlih ukazuju na to da boravak u njemu najčešće nije prelazio godinu dana. [10 p12] No i takav skroman dom za samotna i ostarela lica značio je dosta, obezbeđivao je elementarni humani odnos prema ovoj populaciji, kako od strane brojnih potpornih udruženja, tako i od pojedinaca, a grad lišavao ružnih slika tumaranja i prosjačenja staraca. [10 p12] 
Ono što se kao zaključak, međutim, nameće jeste to da od ovog perioda započinje odlučnija državna intervencija koja je vodila institucionalnim promenama koje će kasnije biti od značaja za nastanak procesa konstruisanja starosti kao društvenog problema u samostalnoj devetnaestovekovnoj Srbiji. Označene promene, $\mathrm{u}$ najkraćem, dovele su do osnivanja domova za gradsku sirotinju iz kojih će postepeno nastajati domovi za stara lica.

\section{Neki od preduslova za organizovano zbrinjavanje starih u Srbiji}

Preduslovi za nastanak organizovanog zbrinjvanja starih na teritoriji srpske države u XIX veku nastali su, kao i u ranijim primerima, iz pokušaja rešavanja problema narastajuće gradske sirotinje. Ovi preduslovi vodili su otpočinjanju potprocesa konstrusanja starosti kao društvenog problema u XX veku. Označeni period, naime, bio je obeležen neizdiferenciranim bavljenjem problemom starijih koji su se uz nevoljnike različitih vrsta „utapali” u širi problem siromaštva. Ipak, pokušaje pronalaženja rešenja moguće je naći u kompleksnom odnosu države i pojedinca koji je podrazumevao kontrolu, između ostalih, marginalizovanih pripadnika ondašnjeg društva. Ovaj odnos razvijao se u okviru tzv. policijske države, koja je vladala ukazima i uredbama, prethodeći pravnoj državi, [11 p26, 12 p54] a za ovaj prilog od značaja je i to da je u nadležnosti lokalne policije bilo i staranje o svim socijalnim pitanjima. Držanje pod kontrolom marginalaca, odnosno briga o „bednima” i „nevoljnima", u prvom redu bolesnima, istovremeno je i začetni oblik staranja o starima budući da su oni predstavljali znatan broj građana na margini na kojoj su se našli istupanjem iz aktivne sfere rada. Pokušaj držanja prosjaka pod kontrolom rezultirao je, između ostalog, osnivanja Sirotinskog fonda nakon popisa građana koji su se bavili prosjačenjem, kao i onih koji nisu mogli samostalno da se izdržavaju, 1846. godine. Međutim, na polovini XIX veka još nije moguće izdvojiti vidove domskog zbrinjavanja siromašnih i, među njima, starih. Ovu ulogu, naime, i dalje je imao gradski špitalj.

Jedan od preduslova za kasnije konstruisanje starosti kao društvenog problema bio je i porast broja stanovnika gradova, u prvom redu, muškaraca (Zvanični popisu iz 1869. godine pokazuje da je u Beogradu živelo 20.506 žitelja, od toga 12.233 muškarca i 8.273 žene). [13 pp 7-30] Ovakva demografska slika grada uticala je i na porast broja samaca među kojima će se brojčano uvećavati i broj ugroženih staraca nakon napuštanja sfere rada.

Drugi važan preduslov podrazumevao je donošenje Zakona o uređenju sanitetske struke i o čuvanju narodnog zdravlja iz 1881. godine koji je omogućio razvoj zdravstvenih prilika. Jedna od najvažnijih odluka jeste da se na nivou države u Nišu osnuje sirotinjski dom koji bi bio finansiran iz Sanitetskog fonda na šta upućuje član 28. O sirotinjskom domu za telesno nesposobne. Do osnivanja dolazi 1902. godine, a kao osnovna funkcija izdvaja se zbrinjavanje: dece, ubogaljenih, slepih, starih, umobolnih... Označeno izjednačavanje u problemu koji je široko obuhvatao različite ne- 
voljnike, međutim, biće moguće registrovati i u kasnijem periodu pa i u savremenom dobu. ${ }^{3}$

\section{Prve organizovane akcije za smeštaj starih i njihovi rezultati}

Organizovane akcije za smeštaj starih javljaju se nakon Prvog svetskog rata. Karakteriše ih orijentacija ka ugroženoj staroj populaciji koja nastavlja da biva ujedinjena u problemu s nevoljnicima različitog profila izjednačenih po siromaštvu. Ono što označeni period čini značajnim jeste činjenica da se u njemu stari postupno prepoznaju kao zasebna kategorija društva čiji se problemi moraju raševati.

Prve mere, naime, bivaju donete kao posledice mnogobrojnih uticaja. Među njima, najznačajniji se odnose na zakasnelu industrijalizaciju koja rezultira važnim društvenim promenama a koje se, između ostalog, odnose i na polje socijalne politike $i$, sledstveno, na organizovanu brigu o starima. Istovremeno, određene ustanove nastaju kao odraz opšte modernizacije, s tim da među njima u ovom periodu i dalje nema onih koje bi bile orijentisane isključivo ka starijoj populaciji. Zbog toga bi bilo ispravno prihvatiti viđenje po kojem se organizovana briga o starima „kretala sličnim tokovima kao i u razvijenim zemljama Zapada, samo su se te tendencije javile u nas nešto kasnije”. [14 p 9]

Praksa koja postepeno počinje da se profiliše oslanjala se na principe ranije razvijene na teritoriji vojvođanskih gradova, s tim da su rešenja bila uobličena i zakonskim rešenjima ${ }^{4}$ koja su nalagala da označenu brigu preuzima Opština. Pored sfere koju je na ovaj način kontrolisala država, u onovremenom pokušaju saniranja konkretnih problema učestvovala su i tzv. humana društva, kao i pojedinci. Praksa o kojoj je reč podrazumevala je otvaranje domova u gradovima u kojima je bio izražen problem siromaštva koje se, nakon kriznog ratnog perioda, dodatno produbljivalo prilivom seoskog stanovništva u gradove.

Primera ima više, ali će ovom prilikom pažnja biti skrenuta samo na pojedine na čijim će se temeljima u kasnijem periodu otvoriti specijalizovani domovi za penzionere i stare. Dom Milosrđa počinje da radi kao rezultat delovanja humanitarnih organizacija u Kragujevcu 1920. godine. [15] Zanimljivi su nazivi koje je promenio dom u Šapcu u koji se prvi štićenici useljavaju 1924. godine. Dom staraca $i$ starica Šabac bio je nazivan i: Azil, Azil za stare i iznemogle, Opštinski azil iznemogli staraca i starica, Azil za starce, Opštinski azil, Dom za stare i iznemogle, Dom iznemogli staraca $i$ starica, Dom ubogi staraca i starica, Dom za iznemogle. [23] Sirotinjski dom u Kruševcu Opština je sazidala 1926. godine pored groblja kako bi se lutajući starci, invalidi i ostali prehranili namirnicama koje su iznošene na daće. [16 pp 27-31] Domu staraca $i$ starica u Beogradu finansirao se iz opštinskih sredstava. Bio je veći

3 S izuzetkom dece oko kojih će vremenom biti konstruisani zasebni društveni problemi.

4 U zakonska rešenja uvedene su tekovine onovremene Evrope koje su s jedne strane poslužile kao uzor, dok su s druge strene predstavljale i uzor koji se morao slediti usled potpisivanja mirovnih ugovore nakon Prvog svetskog rata. [22] 
od ostalih tako da je mogao da primi i preko sto korisnika. [17] U Jagodini je 1934. godine otvoren Dom za iznemogle starce, starice i bogalje u kući blizu groblja u koju su smeštani prosjaci na inicijativu ženskih humanitarnih društava. [18] Primer osnivanja doma na inicijativu pojedinca jeste Dom za iznemogle srpske građane u Knjaževcu. Podignut je sredstvima zaveštanim u testamentu Nikole Spasića [18 pp 7-13] namenjenim podizanju bolnica i doma za stare i iznemogle srpske građane.

$\mathrm{Na}$ osnovu do sada pokazanog, moguće je zaključiti da su dvadesete i tridesete godine 20. veka vreme kada se izraženije javlja praksa osnivanja domova za ugrožena lica. Kroz ovu praksu, moguće je uputiti i u to, postepeno se razvijala i delatnost domskog zbrinjavanja starih. Ipak, valja naglasiti još jednom, ova delatnost nastaje kao mera saniranja problema siromaštva kao šireg društvenog problema u okviru kojeg se u označenom periodu stiču uslovi za prepoznavanje problema skopčanih sa starijom populacijom.

\section{Domski smeštaj nakon Drugog svetskog rata}

Posleratni period obeležilo je iseljavanje domova za stara lica (mahom u ruralne zone) čime je stvoren privid delatnog diskontinuiteta, pa i prostor za donošenje pogrešnog zaključka da istorija domskog zbrinjavanja starih počinje nakon Drugog svetskog rata. Međutim, umesto toga, moguće je detektovati samo prostorni diskontinuitet kao izraz ideološkog „raskidanja” sa prošlošću koja je, u okviru konkretne delatnosti, bila definisana kao nazadna i pogrešna. Nove strategije, međutim, čini se da samo uklanjaju siromašne od očiju javnosti, među njima i stare, a da se principi na kojima su građenje ideje o načina na koji bi ih trebalo zbrinjavati i negovati u ovom periodu nisu bitnije razlikovali od pređašnjih.

Pitanja iz oblasti socijalnog staranja regulisala je država. Prva sprovedena mera, kao što je napomenuto, podrazumevala je iseljavanje korisnika iz domova koji su pre rata postojali u pojedinim gradovima ${ }^{5}$. Domski objekti, dalje, menjali su namenu tako da je stvorena klima iz koje će se kasnije razviti viđenje da počeci domskog zbrinjavanja starih datiraju iz pedesetih godina 20 . veka što se dovodilo u vezu s pojavom nove discipline - socijalnog rada, u istom periodu. Primera prostornog diskontinuiteta, koji stvaraju privid delatnog, ima više. Dom u Kragujevcu je posle rata radio kraće vreme, nakon čega su prostorije izdavane kao stambeni prostor. [15 p 11] Šabački dom je, takođe, nastavio da prima korisnike i posle rata ali je 1955. godine iseljen u Dumaču. [ 23 p 22] U dom u Knjaževcu posle rata najpre su useljena ratna siročad, da bi kasnije postao Dom za vaspitanje mladeži. [21] Jagodinski dom, čiji su stari korisnici poslati u kragujevačku ustanovu, postaje Šegrtski dom. [18] Sirotinjski dom u Kruševcu nakon rata postaje dom za nezbrinute osobe, dok najzad nije predat na rasposlaganje Odeljenju za stambene poslove 1957. godine [16 p 30], a korisnici iseljeni u Dom za nezbrinute u selu Jabukovac kod Prahova i u Dom za nezbrinute u selu Aleksandrovac kod Požarevca. Sirotinjski dom iz Niša počeo je da preseljava korisnike u aleksinački

5 Praksa preseljavanja domova, ipak, nije obuhvatila domove ranije otvorene na teritoriji Vojvodine. 
Dom staraca 1948. godine. Dom u Aleksincu zvanično je registrovan 1956. godine. [24 p 17] I slučaj beogradskih domova potvrđuje praksu iseljavanja. Prema pisanju Petra Manojovića, u Beogradu je do početka rata postojalo više staračkih domova (oko 650 mesta) da bi nakon osolobođenja svi domovi bili preseljeni u unutrašnjost.

Označeni uslovi olakšali su konstruisanje „prekretnice” kada je reč o institucionalnoj brizi o starima. Naime, stvorena je slika o tome da su prvi domovi za stare počeli da se zidaju pedesetih godina, a da se praksa nastavila i šezdesetih, sedamdesetih i osamdesetih godina kada se osnivanivaju gerontološki centri u najvećoj meri posvećeni stanovanju i nezi penzionera. Ovome je pogodovalo sazdavanje penzionisanog dela društva u punom obimu do kojeg dolazi u ovom periodu kada počinje da se razvija i perspektiva koja dobno određenje za starost povezuje sa periodom izlaska iz aktivne sfere rada i sticanjem prava na penziju; [1] dok je, sa druge strane, nastavila da paralelno postoji i vizura koja uporno izjednačava starost i siromaštvo, kao odraz označenog kontinutiteta.

Raskidanje veze između specijalizovane brige o starima i prethodećih praksi orijentisanih ka različitim „drugima” omogućila su, u najkraćem, najmanje dva uslova. Prvi podrazumeva definisanje ove prakse kao začetne forme proistekle iz ideološkog raskidanja s prošlošću novog društva nastalog posle Drugog svetskog rata koje, makar deklarativno, zagovara unapređeni odnos prema starima; dok drugi biva olakšan profesionalizacijom te prakse (kroz delatnost socijalnog rada i sazdavanja gerontologije na ovim prostorima) koja je vlastitu istoriju „preklopila” s istorijom označene delatnosti. Narastanje broja penzionera i učestvovanje njihovih organizacija u izgradnji domova za penzionere dodatno je pozitivno delovalo na formiranje ideje da bi istoriju organizovanog smeštaja u starosti valjalo razumeti kao istoriju gerontoloških centara. Ipak, kada je reč o mreži i kapacitetima ostaje zaključak da se manjkavosti iz ovog perioda prenose i na današnje uslove. Prema podacima iz 2008. godine kapacitet je bio $0,6 \%$ u odnosu na broj lica starijih od 60 ili 65 godina. [19] Razgranost mreže u Vojvodini upućuje na pređašnje faze razvoja ove delatnosti, dok činjenica da se današnji domovi nalaze duž autoputa govore o posleratnim strategijama rešavanja ovog problema, ali i o tome da postoje cele oblasti nepokrivene domskim smeštajem.

Kao jedan od zaključaka valjalo bi istaći i to da se „drugost”, nasuprot deklarativnom zalaganju za poboljšanje kvaliteta života starih u označenom periodu, uviđala u njihovom iseljavanju što je, dalje, rezultiralo dvostrukim sklanjanjem, kao pojedinaca, tako i njihovog zajedničkog problema, iz javne sfere 6 . Druga karakteristika „drugosti” ogledala se u tome da označeni problem nije spadao $u$ red, za rešavanje, urgentnih problema.

6 Samo smeštanje u dom predstavlja uklanjanje iz javne sfere; dok premeštanje domskih kapaciteta u ruralne zone ili unutrašnjost može biti posmatrano kao dodatno sklanjanje problema od lica javnosti. 


\section{Savremeno konstruisanje drugosti na primeru mreže domova i kapaciteta}

$\mathrm{Na}$ osnovu do sada rečenog, moguće je zaključiti da je starost kao društveni problem, u onom delu u kojem je on skopčan sa organizovanom brigom i stanovanjem, proistekla iz mera usmerenih ka rešavanju šireg problema siromaštva koji je pored starih u problemu ujedinjavao i različite, za društvo, „druge”. Nemogućnost organizovanja starih i dugotrajni proces izdvajanja iz korpusa najpre odraslih, [25] a onda i svakovrsnih nevoljnika uticala je na to da su i danas prepoznatljivi mehanizmi koji, obezbeđivanjem istog smeštaja, izjednačavaju različite kategorije nemoćnih građana, bilo da se radi o nemoći da se samostalno izdržavaju ili samostalno brine o sebi. Ovi mehanizmi danas su osnaženi izjednačavanjem pod velom socijalne potrebe. Preciznije: Usisavajući kriterijum socijalne potrebe, eufemiziranjem nemoći, bilo da je ona posledica siromaštva ili telesne $\mathrm{i} /$ ili mentalne karakteristike, mnoge „druge” smešta izvan očiju javnosti, ravno u domove za stara lica. Objedinjavajuća nemoć trebalo bi da bude shvaćena i kao ekonomska, ali i kao politička, budući da se odnosi na nemogućnost učešća u kreiranju socijalne ili bilo koje druge politike koja bi imala direktnog uticaja na ovde analizirani problem. [3 p 395]

Zakonsko rešenje za smeštaj različitih „drugih” tj. nemoćnih u staračke domove, dakle, iznađeno je u okviru definisanja stanja socijalne potrebe ${ }^{7}$. Ona podrazumeva situaciju kada pojedinci, pa i stari pojedinci, nisu u mogućnosti sa samostalno vode računa o sebi ili to mogu u veoma ograničenoj meri. [20 p 617] Ovakva perspektiva vodi brisanju razlika među različitim korisnicima, ali i razlika između starijih korisnicima, a koje gerontološka literatura ističe kao veoma važne budući da se za cilj postavlja zadovoljavanje individualnih potrebe svake stare osobe, [26] time i svakog korisnika domske usluge. Ovo formalno izjednačavanje proizvod je definisanja kriterijuma za smeštanje lica u dom koje propisuje resorno Ministarstvo, a koje je 2012. godine domske kapacitete redefenisalo u kapacitete za stare i odrasle. Zakon o socijalnoj zaštiti [27] korisnike socijalne zaštite deli na maloletna i punoletna lica, pri čemu su punoletna lica definisana kao odrasla (između 26 do 65 godina) i kao starija (preko 65 godina).

Da bi promena koja je nastala bila u potpunosti uočljiva, valja uporediti Uredbu o mreži ustanova socijalne zaštite marta 2012. godine, [28] donetu na osnovu člana 63. aktuelnog Zakona o sicijalnoj zaštiti kojom se utvrđuje mreža ustanova socijalne zaštite za pružanje usluge domskog smeštaja za „odrasle i starije”, i Odluku o mreži ustanova socijalne zaštite za smeštaj korisnika [29] iz 2008. godine. Potonja je kao ustanove za zaštitu odraslih lica određivala: domove za odrasla invalidna lica i lica sa čulnim oštećenjima; zavode za odrasla lica ometena u mentalnom razvoju i duševno obolela lica; domove za odrasla lica ometena u mentalnom razvoju; domove za duševno obolela lica; domove za smeštaj starih lica; gerontološke centre (s namenom smeštaja starih lica). Suprotno tome, današnja mreža prema tipu korisnika podelje-

7 I kada su stari u pitanju. 
na je u pet kategorija tj. tipova: prvi tip čine ustanove za smeštaj odraslih i starih; drugi tip orijetisan je ka odraslima i starima i odraslima i starima sa intelektualnim i mentalnim teškoćama; treći tip profilisan je na način da uključuje smeštaj odraslih i starijih sa intelektualnim i mentalnim teškoćama; četvrti tip ustanova je namenjen odraslim i starijim korisnicima sa telesnim teškoćama; peti tip obezbeđuje smeštaj odraslih i starijih sa senzornim oštećenjima.

Izjednačavanje i ujedinjavanje do kojeg je došlo i na formalnom planu, prema kojem se u istim ustanovama nalaze stariji i odrasli, ipak, nije novina u delatnom smislu, kao što je ranije pokazano. Na ovom mestu valja skrenuti pažnju na to da su označena ujednačavanja sada i formalno legalizovana i da više ne postoje prepreke da se na istom mestu nađu i mlađa socijalno ugrožena lica ili mlađa lica kojima zdravstveni problemi onemogućavaju samostalni život, prihički izmenjena lica različite dobi, izbegla lica bez trajnog rešenja boravka, stara lica koja su socijalno ugrožena, dementna, psihički obolela... ili stari i penzioneri bez nekog od nabrojanih problema. $\mathrm{Na}$ ovaj način, ne samo da se otvara prostor za neadekvatnu brigu o starom korisniku doma, nego se taj isti prostor otvara i za problem svakog korisnika, koji ne može biti adekvatno rešavan bez specijalizovane medicinske brige ${ }^{8}$.

\section{Završna razmatranja}

Pokušaj osvetljavanja procesa konstruisanja starosti kao društvenog problema, u onom delu u kojem se on odvijao kroz razvoj domskog smeštaja starih, podrazumevao je istovremeno i analizu konstruisanja "drugosti” u okviru koje je starost, neretko, sagledavana u prethodna dva stoleća. Ova karakteristika, ukratko, ne odvaja starost od karakteristika ostalih marginalizovanih ovde analiziranih grupa nego, suprotno tome, postaje moguće pratiti istorijski sled u kojem su nevoljnici različitog profila, među njima i stari, sagledavani kao kategorija društva koja zbog nemoći, najčešće proistekle iz siromaštva, mora biti zbrinjavana u okviru domskog smeštaja. Ovakvi ishodi, koji su u različitim državnim okvirima i različitim ideološkim sistemima, kako je pokazano, zadržavali iste ili slične principe nege i zbrinjavanja, proizvod su višestrukih faktora. Jedan od njih, svakako, podrazumeva i nemogućnost samoorganizovanja starije populacije, koja često i jeste pogođena siromaštvom i sa njom skopčanim svakovrsnim problemima, ali i nemogućnost samoorganizovanja koje bi vodilo ka individualnom rešavanju problema ostalih „drugih” za koje društvo kao poslednju „stanicu” određuje domove za stara lica. Ova, više puta potvrđena, nemoć odupiranja rezultirala je dugotrajnim potencijalom za nemogućnost zadovoljenja zdravstvenih i drugih potreba svih korisnika domova, kako starih, tako i onih koji im se ujedinjavanjem u problemu pridružuju, a to su najčešće: psihički izmeđena lica, mentalno i emotivno nedovoljno razvijene osobe, socijalo ugroženi, izbegli, bolesni...

8 Kada je reč o specijalizovanoj medicinskoj brizi u starijoj dobi, od značaja je ukazati i na problem upadljivog pomankanja stručnog kadra u oblasti gerontopsihijatrije bez koje ovakve ustanove ne mogu da izađu u susret potrebama najstarijih korisnika. 
Ovakva slika ne samo da uporno istrajava i, najzad, biva legalizovana preinačenjem domova za stare u domove za stare i odrasle 2012. godine, nego predstavlja i pokazatelj da se odnos prema starima i starosti, kada se $\mathrm{u}$ fokusu nađe biološka karakteristika tj. zdravstveni aspekt, nije značajnije razlikovao ni u drugim, često ugledajućim, sredinima. Na to upućuje stav istoričara starosti Žorža Minoa: „Star čovek, nezanimljiv pacijent zato što se izlečiti ne može, prognan je u starački dom" [25 p 14] a sa njim, valja dodati, našli su se i svi, za društvo, „neizlečivi” - „drugi”. Ovo pretapanje socio-kulturne i zdravstveno-biološke karakteristike, čini se, nastaviće da stare i ostale „druge” drži podalje od važnih društvenih pitanja i fokusa javne sfere.

\section{Reference:}

1. Milosavljević LjM. Antropologija starosti: Penzije. Konstruisanje starosti kao društvenog problema kroz penzije - od prvih penzionera do panzionih fondova. Beograd: Srpski genealoški centar - Odeljenje za etnologiju i antropologiju Filozofskog fakulteta; 2014.

2. Spector MA, John I. KI. Social Problems: A Re-Formulation. Social Problems. 1973; 21(2): 145-159.

3. Milosavljević LjM. Konstruisanje starosti kao društvenog problema [disertacija]. [Beograd (RS)]: Univerzitet u Beogradu; 2013.

4. Milosavljević LjM, Pišev M. Prilog proučavanju urbanog kulturnog nasleđa putem dekonstruisanja procesa konstruisanja starosti kao društvenog problema u Srbiji: preliminarna razmatranja. U: Sinani D. Urbani kulturni identiteti i religioznost u savremenom kontekstu. Beograd:Srpski genealoški centar - Odeljenje za etnologiju i antropologiju Filozofskog fakulteta; 2013.

5. Kočović DR. Razvoj socijalne politike Jugoslavije. Beograd: Udruženje stručnih radnika socijalne zaštite Republike Srbije; 2002.

6. Тимотијевић МИ. Рађање модерне приватности: приватни живот Срба у Хабзбуршкој монархији од краја 17. до почетка 19. века. Београд: Clio; 2006.

7. Пушкар ВО. Предговор за Траг записан у времену: 35 година рада и развоја Геронтолошког центра „Нови Сад”. У: аутори Кресић М, Дрча Ј. Нови Сад: Геронтолошки центар „Нови Сад”; 1999.

8. Belić BR. Gerontološki centri Vojvodine. Novi Sad: Skupština Autonomne Pokrajine Vojvodine; 2006.

9. Улмер ГА. Просјаци у Суботици крајем XVII и првој половини XIX века: (у време слободног краљевског града). Суботица: Историјски архив; 1994.

10. Шајтинац СТ. Геронтолошки центар Зрењанин: век организоване друштвене бриге о остарелим лицима: [1902-2002]. Зрењанин: Геронтолошки центар; 2002.

11. Костић ЛА. Административно право Краљевине Југославије II. Београд: Издавачко и књижарско дредузеће Геца Кон А.Д; 1936.

12. Јовановић ВЛ. Државна власт и појединац. У: Столић А, Макуљевић Н. Приватни живот код Срба у деветнаестом веку: од краја осамнаестог века до почетка Првог светског рата. Београд: Clio; 2006. 
13. Милорадовић ГО, Стојановић ДУ, Ристовић МИ, Перишић МИ, Јовановић МИ. Прва деценија у независној држави. У: Прпа Б. Живети у Београду: документа Управе града Београда. Књ. 4, 1868-1878. Београд: Историјски архив Београда; 2006.

14. Павловић БР. Далека прошлост и брига о старим људима. У Стевовић В. Друга кућа: осма деценија бриге о старим људима, 35. година Дома за старе и пензионере. Крагујевац: Геронтолошки центар; 1997.

15. Стевовић ВЛ. Друга кућа: осма деценија бриге о старим људима, 35. година Дома за старе и пензионере. Крагујевац: Геронтолошки центар; 1997.

16. Миљојковић ДУ. Сиротињски дом у Пећкој улици. У: Дамњановић Ж. Крушевац својој старости: Геронтолошки центар Крушевац. Крушевац: Геронтолошки центар; 1996.

17. Лазаревић ВА. Социјално стараје у београдској општини. Београд: Штампарија „Дом"; 1927.

18. Ветнић СА. Дом стараца и старица у Јагодини 1934-1944: (поводом 60-огодишњице од оснивања првог Дома стараца и старица у Јагодини). Јагодина: Дом за стара лица и пензионере; 1994.

19. Dinić DR. Mreža gerontoloških kapaciteta u Srbiji - vodič. II dopunjeno i izmenjeno izdanje. Beograd: Gerontološko društvo Srbije; 2008.

20. Динић ДР. Пилотирање новог модела збрињавања остарелих особа ангажовањем хранитељске породице и геронто-хранитељице. Политичка ревија. 2008; 7(2): 609632.

21. Ивановић М. ДР, Перић Д. МИ. 25 година Геронтолошког центра у Књажевцу: осма деценија друштвене бриге о старима у Књажевцу. Књажевац: Геронтолошки центар „Књажевац”; 2007.

22. Чалић МА. Социјална историја Србије 1815-1941: Успорени напредак у индустријализацији. Београд: Clio; 2004.

23. Гајић БР. Трагом развоја Геронтолошког центра. Шабац: Геронтолошки центар; 1994.

24. Miletić D. Pola veka naše kuće. Gerontološki centar „Jelenac” u Aleksincu 1948-1998. Aleksinac: Gerontološki centar „Jelenac”; 1998.

25. Миноа ЖО. Историја старости: од антике до ренесансе. Сремски Карловци, Нови Сад: Издавачка књижарница Зорана Стојановића; 1994.

26. Beljošević DR. Kakvi su nam domovi za stare potrebni. U: Manojlović P. Društvo starost, Zbornik referata i saopštenja knj. 1. Beograd: Gerontološko društvo Srbije; 1978.

27. Zakon o socijalnoj zaštiti 2012. [internet 17. 3. 2013]. Dostupno na: http://paragraf.rs/ propisi/zakon_o_socijalnoj_zastiti.html

28. Uredbu o mreži ustanova socijalne zaštite marta 2012. godine. [internet 17. 3. 2013]. Dostupno na: http://www.minrzs.gov.rs/sektor-za-brigu-o-porodici-zakoni.php

29. Odluku o mreži ustanova socijalne zaštite za smeštaj korisnika 2008. [internet 17. 3. 2013]. Dostupno na: http://www.podaci.net/_gSRB/propis/Odluka_o_mrezi/O-muszsk03v0851. html 


\section{Summary}

Long-lived intertwining of socio-cultural as well as health-related and biological aspects of old age is shown by an example of old people's homes where the last haven is also found by, in the eyes of the society, the "others". Keeping track of the developments in placing the elderly in care homes, from poorhouses to modern gerontology centres, provided a basis for understanding the manner for constructing the designated characteristic of the "otherness". This is an enduring process, creating an almost indestructible link between the old and the corps of all kinds of unfortunates, most often united by poverty.

Rad primljen: 3. 9. 2014.

Recenziran: 30. 9. 2014.

Prihvaćen: 9. 10. 2014. 